\title{
Linking Person-Job Fit, Person-Organization Fit, Employee Engagement and Turnover Intention: A Three-Step Conceptual Model
}

\author{
Mumtaz Ali Memon ${ }^{1}$, Rohani Salleh ${ }^{1} \&$ Mohamed Noor Rosli Baharom ${ }^{1}$ \\ ${ }^{1}$ Department of Management and Humanities, Universiti Teknologi PETRONAS, Perak, Malaysia \\ Correspondence: Mumtaz Ali Memon, Department of Management and Humanities, Universiti Teknologi \\ PETRONAS, Bandar Seri Iskandar, 31750 Tronoh, Perak, Malaysia. E-mail: mumtazutp@yahoo.com
}

Received: August 31, $2014 \quad$ Accepted: December 19, $2014 \quad$ Online Published: December 20, 2014

doi:10.5539/ass.v11n2p313 URL: http://dx.doi.org/10.5539/ass.v11n2p313

\begin{abstract}
Past studies revealed that the existence of congruence between employees and their job as well as organisation produces more favourable attitudes and behaviours. Although considerable research has been conducted on the person-job (P-J) fit and person-organization (P-O) fit, an in depth review of the literature identifies several research gaps. First, studies have largely focused on examining P-J fit and P-O fit separately. In addition, the relationship of P-J fit and P-O fit, and employee engagement has been less discussed. Lastly, most often studies investigated how antecedents predict outcomes but minimal effort has been made to explore the consequences of these outcomes. This paper makes a twofold contribution. First, it conceptually integrates both P-O fit and P-J fit into a single model. Second, the paper proposes a three-step model that theoretically links P-J fit and P-O fit (antecedents) to employee engagement (outcome) and turnover intention (consequence). The addition of a third-step would support the evaluation of the outcomes (in terms of the consequences of the overall model) and extend the overall scope of the framework. Social exchange theory, Lewin's field theory, multidimensional model of employee engagement and self-concept-job fit theory are adopted in developing the theoretical linkages among the constructs. Recommendations for future studies are proposed.
\end{abstract}

Keywords: person-job fit, person-organization fit, employee engagement, turnover intention

\section{Introduction}

Empirical evidence indicates that organizations that successfully retain their top talent will significantly thrive (Holtom, Mitchell, Lee, \& Inderrieden, 2005). Although both academicians and practitioners believe that human capital is the most valuable asset to an organization, the retention of high skilled talent has always been one of the major challenges (Boswell, Ren, \& Hinrichs, 2008). It has been noted that high voluntary turnover hampers the strategic objectives of organizations and becomes a severe threat to their competitive advantage. Undeniably, the loss of high skilled talent not only creates financial constraints (Juhdi, Pa'wan, \& Hansaram, 2013), it also affects the productivity of the organization (Johnson, 1995), low morale of the other employees (Johnson, 1995), as well as loss of organizational memory (Huber, 1991). The cost incurred in each voluntary movement is equivalent to approximately $25 \%$ to $33 \%$ of the annual salary of each of the individuals who leave (Bitzer, 2006). Despite the severe consequences this creates, organizations around the globe are constantly facing a high number of voluntary quits (Memon, Salleh, Baharom, \& Harun, 2014; Memon, Salleh, Harun, Rashid, \& Bakar, 2014).

Parsa, Tesone, and Templeton (2009) believe that the flaws in the selection process of the organizations could be one of the reasons for such high rate of voluntary turnover. In short, it may be possible that selected individuals do not fit in with the organization's environment, and, ultimately, decide to leave that organization for a better fit. Past studies revealed that the existence of fit produces more favourable attitudes-experience, greater well-being and perform better (Hoffman \& Woehr, 2006; Kristof-Brown, Zimmerman, \& Johnson, 2005). The literature often indicated two different forms of fit, such as P-J fit and P-O fit. The P-J fit is defined as the "relationship between a person's characteristics and those of the job or tasks that are performed at work", whereas the P-O fit addresses "the compatibility between individuals and the organization" (Kristof-Brown et al., 2005, p. 284). Both the P-J fit and P-O fit have been found to be significantly negatively related with turnover intention (Arthur, Bell, Villado, \& Doverspike, 2006; Boon, Den Hartog, Boselie, \& Paauwe, 2011). In addition, both are positively linked with job satisfaction, organizational commitment, and organizational citizenship behaviour, and job performance (Biswas \& Bhatnagar, 2013; Cable \& DeRue, 2002; Kim, Aryee, Loi, \& Kim, 2013). 
Despite the fact that considerable research has been conducted on the P-J and P-O fit, an in depth scrutiny of the literature identifies three main issues. First, although both forms of fit have long been the centre of attention for organizational behaviour and industrial/organizational psychology, studies have largely focused on examining them separately (e.g., Guan, Deng, Bond, Chen, \& Chan, 2010; Mostafa \& Gould-Williams, 2014; Singhal \& ChatterJee, 2006; Wheeler, Gallagher, Brouer, \& Sablynski, 2007) rather than incorporating both types in a single model. Second, most of the available research examined the roles of the P-J fit and P-O fit in respect of various individual and organizational outcomes, such as job satisfaction (Biswas \& Bhatnagar, 2013; Wheeler et al., 2007), organizational commitment (Biswas \& Bhatnagar, 2013), organizational citizenship behaviour (Cable $\&$ DeRue, 2002) and turnover (Arthur et al., 2006). In doing so, most often studies investigated that how antecedents predict outcomes. However, minimal effort has been made to explore the consequences of these individual and organizational outcomes.

Drawing on the multidimensional model of Saks (2006), we emphasize the need for a third step, which, so far, is missing. It is expected that the addition of a third-step would support the evaluation of the outcomes (in terms of the consequences of the overall model) of the variables and extend the overall scope of the framework. Lastly, although employee engagement has been a topic of great interest in recent times, to date, little is known about its relationship with P-J fit and P-O fit.

Based on the above argument and past literature, the present paper makes a twofold contribution. First, it integrates both the P-J fit and P-O fit into a single model. Second, the paper proposes a three-step conceptual framework that theoretically links P-J and P-O fit (as antecedents) employee engagement (outcome) and integrates the intention (consequence). As a whole, the paper constitutes a valuable extension to the research on fit, employee engagement and turnover. A brief discussion on the constructs is presented in the following section.

\section{Literature Review}

\subsection{Employee Turnover, Person-job and Person-organization Fit}

The research on employee turnover was first discussed in the pioneering work of March and Simon (1958) concerning the theory of organizational equilibrium. In their classical work, March and Simon (1958) argued that employees tend to stay with an organization if the organization successfully provides sufficient inducement to motivate their most valuable assets. Generally, employee turnover is the termination of the official and psychological contract between the employee and the organization (Krausz, 2002; Macdonald, 1999). The literature indicates two types of turnover; voluntary and involuntary (Price, 1977). Involuntary turnover is the departure of employees that is controlled by the organization (Cao, Chen, \& Song, 2013; Price, 1977). In contrast, voluntary turnover refers to the termination of the organizational membership by an individual of their own accord (Boswell et al., 2005; Bretz et al., 1994). Turnover intention, on the other hand, has evidently been noted as the most immediate and most accurate construct to predict actual turnover (Breuklen, Vlist, \& Steensma, 2004; Mobley, 1977, 1982). It refers to the individual's willingness to voluntarily and permanently withdraw from an organization.

The domain of P-J fit has been defined as the "relationship of person's characteristics and those of the job or tasks that performed at work" (Kirstof-Brown, Zimmerman, \& Johnson, 2005, p. 284). Past studies (e.g., Edwards, 1991; Kristof-Brown, 1996) have conceptualized two basic assumptions of P-J fit: demand abilities, and need-supplies or supplies-value fit. In the former, the employee's knowledge, skills and abilities match with what their job and task require, while the latter happens when the employee's needs, desires, or preferences are met by the jobs that they perform (Kirstof-Brown et al., 2005, p. 285). This subjective assessment of both aspects of the P-J fit (demand abilities and need-supply) contributes to predicting employees' work-related attitudes and behaviours. This concept has been emphasized by several organizational theories, such as the theory of adjustment, well-being and satisfaction. Hence, the P-J fit has consistently been reported as an essential predictor of positive work-related attitudes (Guan et al., 2010).

Evidently, numerous studies conducted in the Western context found that the P-J fit is positively related to job satisfaction, quality of work life, and positive adjustment in new organizations (Cable \& DeRue, 2002; Chatman, 1991; Edwards, 1996; Rice, MacFarlin, Hunt, \& Near, 1985; Spokane, 1985). Guan et al. (2010), who conducted a study in the Asian context, noted that the P-J fit has a significant negative relationship with turnover intention among employees working for various organizations in Beijing, China. Most importantly, the study found that the relationship between the P-J fit and outcome was relatively stronger than the results found in the Western settings (see Cable \& DeRue, 2002). Thus, this confirms that the P-J fit is significantly related to several work-related attitudes and behaviours, particularly employee turnover.

With regard to P-O fit, numerous studies have indicated that fit between individual and organization also 
generates positive outcomes for both the employee and employer (e.g., Kristof-Brown, 1996; Kristof-Brown et al., 2005). P-O fit refers to "the compatibility between individuals and organizations" (Kristof-Brown, 1996, p. 3). In brief, it is defined as the compatibility between the individuals and organizations that occurs when: (a) at least one entity provides what the other needs, (b) they share similar fundamental characteristics, or (c) both (Kristof-Brown, 1996, p. 4). Furthermore, the P-O fit is divided into two main types of fit: First, the supplementary fit, which occurs in a situation when the individual possesses attributes that are similar to those of other members in the organization (Muchinsky \& Monahan, 1987). Second, the complementary fit, which occurs when an individual's characteristics add something new to fill the gap that is so far missing in the organization (Muchinsky \& Monahan, 1987), or, vice versa, with the intention to complement each other (Kirstof-Brown et al., 2005).

Although past studies have indicated that the P-O fit generates positive outcome for both the employee and employer, Cable and DeRue (2002) and Greguras and Diefendorff (2009) stated that the P-O fit is mainly concerned with organizational level outcomes rather than being job focused. For example, with regard to voluntary turnover, several meta-analyses (e.g., Hoffman \& Woehr, 2006; Kristof-Brown et al., 2005; Verquer, Beehr, \& Wagner, 2003) found statistical evidences that compared to those who were perceived to be less fit, individuals who fit with their workplaces tended to stay longer and were less intent on leaving their organization.

\subsection{Employee Engagement \& Turnover}

Though there is no definitive agreement on a formal definition, the term employee engagement has been conceptualized in a number of ways. Kahn (1990) was the first who pointed out that "people can use varying degrees of their selves, physically, cognitively, and emotionally, in work role performances" (p. 692). In his qualitative investigation, Kahn conceptualized engagement as "the harnessing of organization members' selves to their work roles; people employ and express themselves physically, cognitively, and emotionally" (p. 694). He further noted that meaningfulness, safety, and availability are the three conditions associated with engagement at work. A decade later, May, Gilson, and Harter (2004) empirically investigated Kahn's (1990) model and found that all conditions (e.g., meaningfulness, safety, and availability) were significantly related to engagement at work. Besides, Schaufeli, Salanova, Gonzalez-Roma, and Bakker (2002, p. 74) defined engagement as "a positive, fulfilling work related state of mind that is characterized by vigour, dedication and absorption". On the whole, one common agreement in these definitions was the work role of the individual. Nevertheless, Saks (2006), who in his multidimensional model of engagement emphasized two different aspects of engagement - job and organization - argued that, besides their work roles, individuals are also members of the organization. The multidimensional model which consists of three components: antecedents, engagement and consequences, has been widely accepted by scholars in the current literature.

Since engagement refers to meaningfulness, safety, and availability, it can be expected that a high level of engagement generates positive outcomes, organizational success and high financial performance (Bates, 2004; Richman, 2006). This is comparable with Kahn's (1990) conceptualization that employee engagement leads to several individual and organizational level outcomes. In addition, numerous studies have noted that engagement has a negative association with turnover intention. In a meta-analysis of 7939 business units of 36 different companies, Harter, Schmidt, and Hayes (2002) found that engagement was significantly linked to turnover. Likewise, Schaufeli and Bakker (2004), who investigated four organizations located in the Netherlands, found that individuals with a high level of engagement are less likely to be involved in turnover behaviour compared to those with low engagement. Additionally, recent studies also reported similar findings (e.g., Juhdi, Pa'wan, \& Hansaram, 2013), thus confirming that engagement significantly predicts turnover intention.

\subsection{Person-job and Person-organization Fit and Employee Engagement}

May et al. (2004) asserted that psychological conditions play an important role for employees to be engaged. One of the conditions is a good job fit between employees and their job roles (Juhdi et al., 2013). In other words, effective selection of the individuals leads to high engagement for the reason that their skills and abilities match their job requirements. The relationship between P-J fit and engagement can be explained by the conceptualization of Scroggins (2008) concerning the self-concept-job fit towards meaningful work. The concept is similar to the Kristof-Brown (1996) theory of person-job fit in which meaningful work was integrated as one of the antecedents in the model. According to Scroggins (2008), in the self-concept-job fit, employees are more likely to adjust themselves to fit with their job requirements. Furthermore, from a comparable stance, Maslach and Leiter (2008, p. 501) stressed that "the greater the perceived congruity the greater the likelihood of engagement with work". Conversely, a poor level of P-J fit is expected to be linked with low engagement (Warr \& Inceoglu, 2012). 
In addition, P-O fit is widely conceptualized as the congruence between the individual and the organization, and, thus, is anticipated to be linked with employee engagement. According to Vuuren, Veldkamp, Jong, Seydel (2007), within the P-O fit, individuals create a sense of communality of purpose for their employer and increase the level of effectiveness to their role performance, which, ultimately, leads to psychological safety (Biswas \& Bhatnagar, 2013). As safety is also one of the conditions of employee engagement, there is a possibility that a high level of psychological safety may lead individuals to be highly engaged. Moreover, value and goal congruence between both parties (employee and employer) are integral parts of P-O fit; build meaningfulness and psychological attachment (Biswas \& Bhatnagar, 2013); are also two of the conditions of employee engagement. Supporting this argument, in a recent study, Biswas and Bhatnagar (2013) noted that P-O fit was highly related to employee engagement among the employees belonging to organizations located in the north of India.

Although Lewin's field theory mainly focuses on individuals' perceived work environment, delivering an invaluable foundation to the relationship of P-O fit and employee engagement. Lewin (1951) professed that the behaviour of individuals depends on their work environment. The interaction of persons and their work environment therefore develops certain behaviours among individuals. Particularly, individuals with a positive perception about their work environment (organization) are more likely to display positive behaviours. Hence, we expect that employees' perceived fit with their organization stimulates them to perform not only their job role effectively but also to go beyond expectations, which may be interpreted as a high level of engagement for their job and the employer for whom they work.

\subsection{Employee Engagement as a Mediator}

With regard to the mediating role of employee engagement, in his pioneer work on the multidimensional model, Saks (2006) found that employee engagement mediated the relationship between the antecedents and the consequences. In brief, Saks conceptualized job characteristics, perceived organizational support, perceived supervisor support, rewards and recognition, procedural justice and distributive justice as the antecedents, while job satisfaction, organizational commitment, organizational citizenship behaviour and intention to quit were operationalized as the consequences of employee engagement. The study was conducted among 102 employees working in a variety of organizations in Toronto. The findings of the study showed that employee engagement (job and organization) mediated the relationship between antecedents and consequences, as hypothesized earlier. In addition, other evidences were also found confirming the mediating role of employee engagement (e.g., Juhdi et al., 2013; Schaufeli \& Bakker, 2004). Recently, Biswas and Bhatnagar (2013) also found that employee engagement mediated the relationship between person-organization fit and employee engagement. Hence, while we assume that the antecedents (P-O fit and P-J fit) predict employee engagement, past studies have already revealed that employee engagement predicts turnover intention. Certainly, it is believed that employee engagement mediates the relationship between P-O fit and P-J fit (antecedents), and turnover intention (consequence).

\subsection{Social Exchange Theory and Proposed Three-step Conceptual Model}

Social Exchange Theory (SET) (Blau, 1964) provides a robust theoretical account concerning the inter-relationship among P-J and P-O fit, employee engagement and turnover intention. As SET involves in the mutual exchange of intangible socio-economical resources (Blau, 1964), it develops obligations through continuous interactions between parties (Saks, 2006). Reciprocity or repayment of the actions is the key role in the exchange relationship. To put it another way, when individuals are treated positively by their employer, they feel obliged and repay the organization in a similar fashion (Saks, 2006). With regard to P-J and P-O fit, it is conceptualized that when individuals find a positive match with their respective organization; the congruence between the employees perceived fit and the environment creates a sense of obligation to reciprocate. With this in mind, "one way for employees to respond their employers is through their level of engagement" (Saks, 2006, p. 603). Notably, this belief is consistent with the description of Robinson, Perryman, and Hayday (2004) in respect of engagement being a two-way relationship between individuals and the organization. Consequently, a high level of engagement will in fact nurture favourable attitudinal and behavioural outcomes, particularly low turnover, as found in past studies (e.g., Juhdi et al., 2013; Saks, 2006; Schaufeli \& Bakker, 2004).

In view of the above discussion, a three-step model is proposed, as shown in Figure 1. P-J and P-O fit are conceptualized as antecedents, while turnover intention is considered a consequence of employee engagement. Overall, employee engagement serves as a three-fold construct in the proposed model. First, it is an outcome of the P-J and P-O fit. Second, it predicts turnover intention. Lastly, it mediates the relationship between P-J \& P-O fit and turnover intention. 


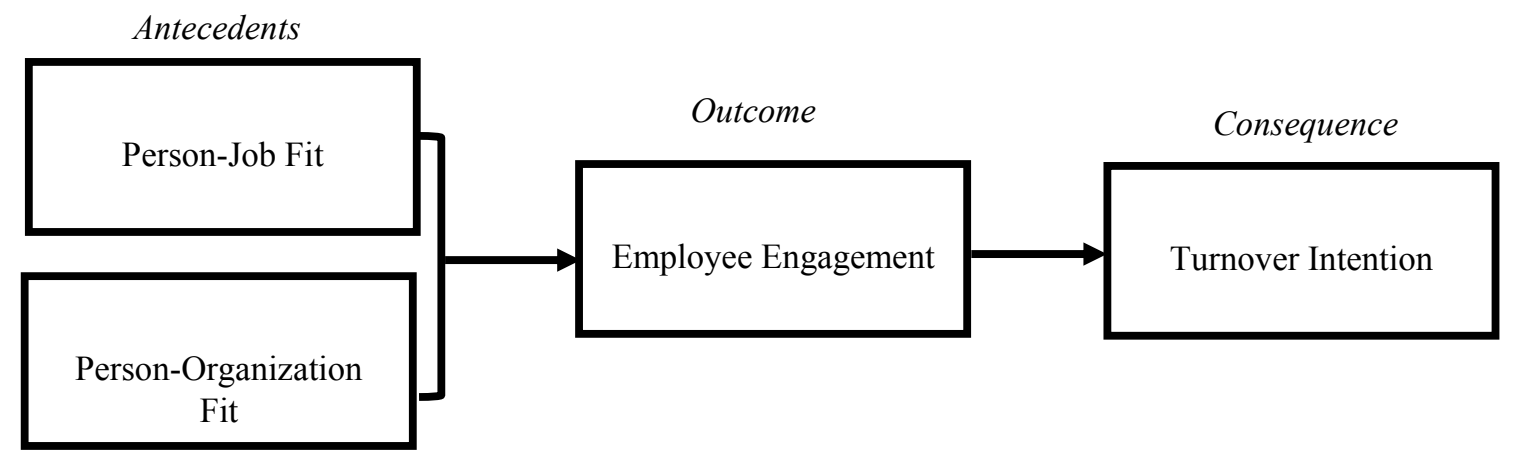

Figure 1. Proposed three-step conceptual model

\section{Conclusion}

P-J and P-O fit-match between an individual's attributes and their surroundings increases the positive emotions, attitudes and behaviours. In other words, when fit occurs, consequently it generates work-related positive attitudinal and behavioural outcomes. Similarly, we expect that high congruity between the employee and the employer will encourage individuals towards a high level of engagement. This relationship can be well understood through the social exchange theory. In a nutshell, when individuals achieve a good fit with their work and organizations, they feel obliged and tend to pay back to their partner in terms of a high level of engagement. Moreover, given that the employee engagement is the centre of attention in contemporary literature due to its negative relationship with turnover intention, it is assumed that individuals with a high level of engagement tend to stay longer and participate less in voluntary withdrawals. Finally, taking all together, when the antecedents (P-O fit and P-J fit) are expected to predict employee engagement, and employee engagement has already been recognized as a strong predictor of consequences (turnover intention), it is conceivable theoretically that engagement mediates the relationship between the antecedents and consequences.

Since the relationship of P-J and P-O fit, and turnover intention has been less discussed with regard to employee engagement, the present paper fills the indicated research gap. It integrates P-O fit and P-J fit, employee engagement and turnover intention in a single framework, which is a relatively unique attempt. Additionally, we go beyond the traditional approaches by proposing a three-step framework that theoretically links P-J and P-O fit (antecedents), and employee engagement (outcome), and integrate turnover intention as a consequence.

Future studies should conceptualize and test other behavioural constructs, especially organizational citizenship behaviour, as a mediator between P-J and P-O fit and turnover intention. In addition, future studies are recommended to validate the proposed framework by using advanced statistical methods, such as structural equation modelling, in order to attain robust results. Given that the presence of moderator could strengthen the relationship between the proposed variables, future studies could integrate exchange ideology as the potential moderator to further extend the proposed model.

\section{References}

Arthur, W. Jr., Bell, S. T., Villado, A. J., \& Doverspike, D. (2006). The use of person-organization fit in employment decision making: An assessment of its criterion-related validity. J Appl Psychol, 91(4), 786-801. http://dx.doi.org/10.1037/0021-9010.91.4.786

Bates, S. (2004). Getting engaged. HR Magazine, 49(2), 44-51.

Biswas, S., \& Bhatnagar, J. (2013). Mediator analysis of employee engagement: Role of perceived organizational support, P-O Fit, Organizational Commitment and Job Satisfaction. Research, 38(1), 27-40.

Bitzer, E. (2006). Strategies for cutting turnover. Security Management, 50(5), 88-92.

Blau, P. (1964). Exchange and power in social life. New York: Wiley.

Boon, C., Den Hartog, D. N., Boselie, P., \& Paauwe, J. (2011). The relationship between perceptions of HR practices and employee outcomes: Examining the role of person-organisation and person-job fit. The International Journal of Human Resource Management, 22(1), 138-162. http://dx.doi.org/10.1080/09585192.2011.538978

Boswell, W. R., Boudreau, J. W., \& Tichy, J. (2005). The relationship between employee job change and job 
satisfaction: The honeymoon-hangover effect. Journal of Applied Psychology, 90, 882-892. http://dx.doi. org/10.1037/0021-9010.90.5.882

Boswell, W. R., Ren, L. R., \& Hinrichs, A. T. (Eds.). (2008). Voluntary Employee Turnover: Determinants, Processes, and Future Directions (Vol. I). London: SAGE Publications.

Bretz, R. D., Boudreau, J. W., \& Judge, T. A. (1994). Job search behaviour of employed managers. Personnel Psychology, 47, 275-301. http://dx.doi.org/10.1111/j.1744-6570.1994.tb01725.x

Breuklen, W. V., Vlist, R. V. D., \& Steensma, H. (2004). Voluntary employee turnover. Combining variables from the 'traditional' turnover literature with the theory of planned behaviour. Journal of Organizational Behaviour, 25, 893-914. http://dx.doi.org/10.1002/job.281

Cable, D. M., \& DeRue, D. S. (2002). The convergent and discriminant validity of subjective fit perceptions. Journal of Applied Psychology, 87, 875-884. http://dx.doi.org/10.1037/0021-9010.87.5.875

Cao, Z., Chen, J., \& Song, Y. (2013). Does total rewards reduce the core employees' turnover intention? International Journal of Business Management, 8(20), 75. http://dx.doi.org/10.5539/ijbm.v8n20p62

Chatman, J. A. (1991). Matching people and organization: Selection and socialization in public accounting firms. Administrative Science Quarterly, 36, 459-484. http://dx.doi.org/10.2307/2393204

Edwards, J. (1991). Person-Job fit: A conceptual integration, literature review, and methodological critique. In C. CLRIT (Ed.), International Review of Industrial and Organizational Psychology (Vol. 66, pp. 283-357). Chichester, UK: Wiley.

Edwards, J. (1996). An examination of competing versions of the person-environment fit approach on stress 1996 , 39, 292-339.

Greguras, G. J., \& Diefendorff, J. M. (2009). Different fits satisfy different needs: Linking person-environment fit to employee commitment and performance using self-determination theory. Journal of Applied Social Psychology, 94, 465-477. http://dx.doi.org/10.1037/a0014068

Guan, Y., Deng, H., Bond, M. H., Chen, S. X., \& Chan, C. C. H. (2010). Person-Job Fit and Work-Related Attitudes among Chinese Employees: Need for Cognitive Closure as Moderator. Basic and Applied Social Psychology, 32(3), 250-260. http://dx.doi.org/10.1080/01973533.2010.495664

Harter, J. K., Schmidt, F. L., \& Hayes, T. L. (2002). Business-unit level relationship between employee satisfaction, employee engagement, and business outcomes: A meta-analysis. Journal of Applied Psychology, 87(2), 268-279. http://dx.doi.org/10.1037/0021-9010.87.2.268

Hoffman, B. J., \& Woehr, D. J. (2006). A quantitative review of the relationship between person-organization fit and behavioral outcomes. Journal of Vocational Behaviour, 68(3), 389-399. http://dx.doi.org/10.1016 /j.jvb.2005.08.003

Holtom, B. C., Mitchell, T., Lee, T., \& Inderrieden, E. (2005). Shocks as causes of turnover: Why they are and how organizations can manage them. Human Resource Management, 44, 337-352. http://dx.doi.org/10.1002 /hrm.20074

Huber, G. P. (1991). Organizational learning: The contributing processes and the literatures. Organization Science (Special Issue: Organizational Learning: Paper in Honour of (and by) James G.), 88-115.

Johnson, A. (1995). The business case for work-family programs. Journal of Accountancy, 180(2), 53-59.

Juhdi, N., Pa'wan, F., \& Hansaram, R. M. K. (2013). HR Practices and Turnover intention: The mediating roles of organizational commitment and organizational engagement in a selected region in Malaysia. The International Journal of Human Resource Management, 24(15), 3002-3019. http://dx.doi.org/10.1080/09 585192.2013 .763841

Kahn, W. A. (1990). Psychological conditions of personal engagement and disengagement at work. Academy of Management Journal, 33(4), 692-724. http://dx.doi.org/10.2307/256287

Kim, T.-Y., Aryee, S., Loi, R., \& Kim, S.-P. (2013). Person-organization fit and employee outcomes: Test of a social exchange model. The International Journal of Human Resource Management, 24(19), 3719-3737. http://dx.doi.org/10.1080/09585192.2013.781522

Kirstof-Brown, A. L., Zimmerman, R. D., \& Johnson, E. C. (2005). Consequences of individuals' fit at work: A meta-analysis of person-job person-organisation, person-group and person-supervisor fit. Personnel Psychology, 58, 281-342. http://dx.doi.org/10.1111/j.1744-6570.2005.00672.x 
Krausz, M. (2002). The many faces of voluntary employee turnover. Voluntary Employee Withdrawal and Inattendance, 53-70. http://dx.doi.org/10.1007/978-1-4615-0599-0_3

Kristof-Brown, A. 1. (1996). Person-organization fit: An integrative review of its conceptualizations, measurement and implication. Personnel Psychology, 49(1), 1-49. http://dx.doi.org/10.1111/j.1744-6570. 1996.tb01790.x

Kristof-Brown, A. 1., Zimmerman, R. d., \& Johnson, E. c. (2005). Consequences of individuals' fit at work: A Meta-analysis of person-job, person-organization, person-group, and person-supervisor fit. Personnel Psychology, 58(2), 281-342. http://dx.doi.org/10.1111/j.1744-6570.2005.00672.x

Lewin, K. (1951). Field theory in social science: Selected theoretical papers. In J. R. Edwards (Ed.), Person-environment fit in organizations: An assessment of theoretical progress (Vol. 2, pp. 197-230). Westport: Greenwood Press.

Macdonald, D. (1999). Teacher attrition: A review of literature. Teaching and Teacher Education, 15(8), 835-848. http://dx.doi.org/10.1016/S0742-051X(99)00031-1

March, J., \& Simon, H. (1958). Organization. New York: Wiley.

Maslach, C., \& Leiter, M. P. (2008). Early predictors of job burnout and engagement. Journal of Applied Psychology, 93, 498-512. http://dx.doi.org/10.1037/0021-9010.93.3.498

May, D. R., Gilson, R. L., \& Harter, L. M. (2004). The psychological conditions of meaningfulness, safety and availability and the engagement of the human spirit at work. Journal of Occupational \& Organizational Psychology, 77, 11-37. http://dx.doi.org/10.1348/096317904322915892

Memon, M. A., Salleh, R., Baharom, M. N. R., \& Harun, H. (2014, 3-5 June 2014). Person-Organization Fit and Turnover Intention: The Mediating Role of Employee Engagement. Paper presented at the International Conference on Leadership and Management (ICLM2014), Kuala Lumpur.

Memon, M. A., Salleh, R., Harun, H., Rashid, R. A., \& Bakar, Z. A. (2014). Training, Engagement, Social Exchange Ideology and Employee Turnover: A Proposed Moderated Mediation Conceptual Framework. Australian Journal of Basic \& Applied Sciences, 8(5), 151-156.

Mobley, W. H. (1977). Intermediate linkages in the relationship between job satisfaction and employee turnover. Journal of Applied Psychology, 62, 237-240. http://dx.doi.org/10.1037/0021-9010.62.2.237

Mobley, W. H. (1982). Employee Turnover: Causes, consequences and control. Addison-Wesley: Reading, MT.

Mostafa, A. M. S., \& Gould-Williams, J. S. (2014). Testing the mediation effect of person-organization fit on the relationship between high performance HR practices and employee outcomes in the Egyptian public sector. The International Journal of Human Resource Management, 25(2), 276-292. http://dx.doi.org/10.1080/095 85192.2013.826917

Muchinsky, P. M., \& Monahan, C. J. (1987). What is Person-Environment Congruence? Supplementary versus complementary models of fit. Journal of Vocational Behaviour, 31, 268-277. http://dx.doi.org/10.1016/0001- 8791(87)90043-1

Parsa, H. G., Tesone, D., \& Templeton, A. (2009). All employees are not created equal: An alternative method of assessing employee turnover. Journal of Foodservice Business Research, 12, 317-330. http://dx.doi.org/10. $1080 / 15378020903344265$

Price, J. L. (1977). The study of Turnover. Ames, IA: Lowa State University Press.

Rainey, H. G. (2003). Understanding and Managing Public Organizations, (3rd ed.). San Francisco, CA: Jossey-Bass

Rice, R. W., MacFarlin, D. B., Hunt, R. G., \& Near, J. P. (1985). Organizational work and perceived quality of life: Toward a conceptual model. Academy of Management Review, 10, 296-310.

Richman, A. (2006). Everyone wants an engaged workforce how can you create it? Workspan, 49, 36-39.

Robinson, D., Perryman, S., \& Hayday, S. (2004). The drivers of employee engagement. Brighton: Institute for Employment Studies.

Saks, A. M. (2006). Antecedents and consequences of employee engagement. Journal of Managerial Psychology, 21(7), 600-619. http://dx.doi.org/10.1108/02683940610690169

Schaufeli, W. B., \& Bakker, A. B. (2004). Job demands, job resources, and their relationship with burnout and 
engagement: A multi-sample study. Journal of Organizational Behaviour, 25, 293-315. http://dx.doi.org/10. 1002/job. 248

Schaufeli, W. B., Salanova, M., Gonzalez-Roma, V., \& Bakker, A. B. (2002). The measurement of engagement and burnout: A two sample confirmatory factor analytic approach. Journal of Happiness Studies, 3, 71-92. http://dx.doi.org/10.1023/A:1015630930326

Scroggins, W. A. (2008). Antecedents and outcomes of experienced meaningful work: A person-job fit perspective. Journal of Business Inquiry, 68-78.

Singhal, A., \& ChatterJee, L. (2006). A person-organization fit-based approach for spirituality at work: Development of a conceptual framework. Journal of Human Values, 12(2), 161-178. http://dx.doi.org/10.11 $77 / 097168580601200205$

Spokane, A. R. (1985). A review of research on person-environment congruence in Holland's theory of careers. Journal of Vocational Behaviours, 26, 306-343. http://dx.doi.org/10.1016/0001-8791(85)90009-0

Verquer, M. L., Beehr, T. A., \& Wagner, S. H. (2003). A meta-analysis of relations between person-organization fit and work attitudes. Journal of Vocational Behaviour, 63(3), 473-489. http://dx.doi.org/10.1016/S00018791(02)00036-2

Warr, P., \& Inceoglu, I. (2012). Job Engagement, Job Satisfaction, and Contrasting Associations with Person-Job Fit. Journal of Occupational Health Psychology, 17(2), 129-138. http://dx.doi.org/10.1037/a0026859

Wheeler, A. R., Gallagher, V. C., Brouer, R. L., \& Sablynski, C. J. (2007). When person -organization (mist) fit and (dis) satisfaction lead to turnover. Journal of Managerial Psychology, 22(2), 203-219. http://dx.doi.org $/ 10.1108 / 02683940710726447$

\section{Copyrights}

Copyright for this article is retained by the author(s), with first publication rights granted to the journal.

This is an open-access article distributed under the terms and conditions of the Creative Commons Attribution license (http://creativecommons.org/licenses/by/3.0/). 